Supplement of Biogeosciences, 13, 1837-1861, 2016

http://www.biogeosciences.net/13/1837/2016/

doi:10.5194/bg-13-1837-2016-supplement

(C) Author(s) 2016. CC Attribution 3.0 License.

(c) (i)

Supplement of

\title{
A process-based model for ammonia emission from urine patches, GAG (Generation of Ammonia from Grazing): description and sensitivity analysis
}

Andrea Móring et al.

Correspondence to: Andrea Móring (a.moring@sms.ed.ac.uk)

The copyright of individual parts of the supplement might differ from the CC-BY 3.0 licence. 


\section{Supplementary material}

\section{S1. Parametrization of $R_{a}, R_{b}, R_{b g}$ and $R_{s t o}$}

4 The value of $R_{a}\left(\mathrm{sm}^{-1}\right)$ is dependent on the stability of atmosphere. An unstable stratification -

5 when perturbing an air parcel it ascends from its initial position - favours smaller $\mathrm{R}_{\mathrm{a}}$, whilst a

6 stable one - when the perturbed air parcel returns to its initial position - favours larger $\mathrm{R}_{\mathrm{a}}$.

7 Atmospheric stability can be determined based on the measurements of the sensible heat flux

$8 \quad\left(\mathrm{H}, \mathrm{J} \mathrm{m}^{2} \mathrm{~s}^{-1}\right)$; for $\mathrm{H}>0$, the stratification is unstable, while for $\mathrm{H}<0$, it is stable. The following 9 parametrization of $\mathrm{R}_{\mathrm{a}}$ was used (following Garland (1977)):

$$
\begin{gathered}
R_{a}\left(z_{w}\right)=\frac{u}{u_{*}^{2}} \quad \text { if } H<0, \\
R_{a}\left(z_{w}\right)=\frac{u}{u_{*}^{2}}-\frac{\Psi_{H}\left(\frac{z_{w}-d}{L}\right)-\Psi_{M}\left(\frac{z_{w}-d}{L}\right)}{k u_{*}} \text { if } H>0,
\end{gathered}
$$

10 where $\mathrm{u}$ is the wind speed measured at $\mathrm{z}_{\mathrm{w}}(\mathrm{m})$ height above ground, $\mathrm{u} *\left(\mathrm{~m} \mathrm{~s}^{-1}\right)$ is the friction velocity, $\Psi_{\mathrm{H}}$ and $\Psi_{\mathrm{M}}$ are the stability functions for heat and momentum flux, respectively, $\mathrm{L}$ (m) is the Monin-Obukhov length, $\mathrm{d}$ is the displacement height of the vegetation, and $\mathrm{k}$ is the

13 Karman constant (see its value together with all the model constants used in the parametrization 14 of the compensation point model in Table S1).

15 In the case of stable conditions, we parametrized $\Psi_{H}$ and $\Psi_{M}$ following Webb (1970):

$$
\Psi_{H}=\Psi_{M}=\frac{-5\left(z_{w}-d\right)}{L},
$$

and for unstable conditions we applied the approach of Paulson (1970):

$$
\begin{gathered}
\Psi_{M}=\ln \left(\frac{1+x}{2}\right)^{2}+\ln \left(\frac{1+x^{2}}{2}\right)-2 \arctan x+\frac{\pi}{2}, \\
\Psi_{H}=2 \ln \left(\frac{1+x^{2}}{2}\right),
\end{gathered}
$$

where: 


$$
x=\left(1-16 \frac{z_{w}-d}{L}\right)^{\frac{1}{4}}
$$

$1 \quad \mathrm{~L}$ and $\mathrm{u} *$ can be obtained from measurements, but in the absence of these, parametrization 2 should be used. Eq. (S7) expresses $\mathrm{u} *$, with $\mathrm{z}_{0}(\mathrm{~m})$ roughness length. $\mathrm{L}$ was derived following 3 Eq. (S8), where $\mathrm{T}(\mathrm{K})$ is the temperature at $2 \mathrm{~m}$ above ground, $\rho\left(\mathrm{kg} \mathrm{m}^{-3}\right)$ is air density, $\mathrm{c}_{\mathrm{p}}$ is the 4 specific heat capacity of dry air, and $\mathrm{g}$ is the acceleration of gravity. As the two parameters ( $\mathrm{L}$ 5 and $\mathrm{u} *$ ) depend on each other, we applied iteration to calculate both.

$$
\begin{gathered}
u_{*}=\frac{k u}{\ln \left(\frac{z_{w}-d}{z_{0}}\right)-\Psi_{M}\left(\frac{z_{w}-d}{L}\right)} \\
L=-\frac{T u_{*}^{3} \rho c_{p}}{k g H}
\end{gathered}
$$

6 The values of $\rho$ can be calculated as a function of atmospheric pressure (p, Pa) and virtual 7 temperature, which is the temperature that the dry air would have if its pressure and density was 8 the same as that of the moist air $\left(\mathrm{T}_{\mathrm{v}}, \mathrm{K}\right)$ :

$$
\rho=\frac{p}{R T_{v}}
$$

9 where $\mathrm{R}$ is the gas constant and $\mathrm{T}_{\mathrm{v}}$ as a function of specific humidity (q) (for actual vapour 10 pressure $\left(\mathrm{e}_{\mathrm{a}}, \mathrm{Pa}\right)$ see $\left.(\mathrm{S} 21)\right)$ :

$$
T_{v}=\frac{T}{1+0.608 q}
$$

11 where

$$
q=\frac{0.622 e_{a}}{p-0.378 e_{a}}
$$

12 Based on Nemitz et al. (2001) for $R_{b}$, we used the formula of Owen and Thomson (1963), 13 where $\mathrm{Re}$ is the Reynolds number $\left(\mathrm{R}_{\mathrm{e}}=\mathrm{u} * \mathrm{Z}_{0} v^{-1}\right.$, with $v$ as kinematic viscosity) and Sc is the 14 Schmidt number $\left(\mathrm{Sc}=v \mathrm{Dg}_{\mathrm{g}}^{-1}\right.$, with $\mathrm{D}_{\mathrm{g}}$ as the diffusivity of ammonia in air):

$$
R_{b}=1.45 \times R e^{0.24} S c^{0.8} u_{*}^{-1} .
$$


1 Nemitz et al. (2001) applied a parametrization for $\mathrm{R}_{\mathrm{bg}}\left(\mathrm{s} \mathrm{m}^{-1}\right)$ for oilseed rape. Based on this $\mathrm{R}_{\mathrm{bg}}$

2 can be expressed as (Schuepp, 1977):

$$
R_{b g}=\frac{\frac{v}{D_{g}}-\ln \left(\frac{\delta_{0}}{z_{l}}\right)}{k u_{* g}},
$$

3 where $\delta_{0}(\mathrm{~m})$ is the height where eddy and molecular diffusivity are the same in magnitude and $4 \mathrm{Z}_{\mathrm{l}}(\mathrm{m})$ is the height of the top of logarithmic wind profile (assumed to be $0.1 \mathrm{~m}$ as for oilseed 5 rape). According to Schuepp (1977), $\delta_{0}$ (Eq. (S14)) is a function of friction velocity at ground 6 level in the canopy $\left(\mathrm{u} * \mathrm{~g}, \mathrm{sm}^{-1}\right)$, which can be derived from the wind speed (Eq. (S15) as an 7 approximation for oilseed rape by Nemitz et al. (2001)).

$$
\begin{gathered}
\delta_{0}=\frac{v}{k u_{* g}} \\
u_{* g}=\frac{1.68 \times u}{20}
\end{gathered}
$$

8 In the parametrization of $\mathrm{R}_{\text {sto }}$ the components $\mathrm{g}_{\text {light, }} \mathrm{g}_{\text {temp }}$ and $\mathrm{g}_{\mathrm{VPD}}$ were derived following 9 Emberson et al. (2000). Whilst $\mathrm{g}_{\text {light }}$ (Eq. (S16)) is expressed as a function of photosynthetically

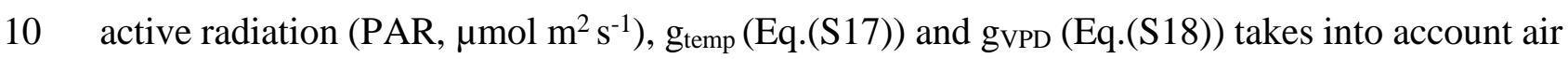
11 temperature $\left({ }^{0} \mathrm{C}\right)$ and vapour pressure deficit (VPD, $\mathrm{kPa}$ ), respectively. The latter is defined 12 (Eq.(S19)) as the difference between saturated ( $\mathrm{e}_{\mathrm{s}}(\mathrm{kPa})$, Eq. (S20)) and actual vapour pressure 13 (e $(\mathrm{kPa})$, Eq. (S21)).

$$
\begin{gathered}
g_{\text {light }}=1-\exp \left(-\alpha_{P A R} \times P A R\right) \\
g_{\text {temp }}=\min \left\{g_{\text {min }},\left(1-\left(\frac{T-T_{\text {opt }}}{T_{\text {opt }}-T_{\text {min }}}\right)^{2}\right)\right\} \\
g_{V P D}=\left\{\begin{array}{cc}
\text { if } & V P D>V P D_{\text {min }} \\
g_{\text {min }} & \text { if } \\
1 & V P D<V P D_{\text {max }} \\
\text { otherwise } & \\
\left(\frac{\left(1-g_{\text {min }}\right)\left(V P D_{\text {min }}-V P D\right)}{V P D_{\text {min }}-V P D_{\text {max }}}+g_{\text {min }}\right) & \\
V P D=e_{s}-e_{a}
\end{array}\right.
\end{gathered}
$$




$$
\begin{gathered}
e_{s}=0.6108 \times \exp \left(\frac{17.27 \times T}{T+237.3}\right) \\
e_{a}=e_{s} \frac{R H}{100}
\end{gathered}
$$

\begin{tabular}{|c|c|}
\hline Model constants & Value \\
\hline \multicolumn{2}{|l|}{ For $R_{a}$ and $R_{b}$} \\
\hline k (Karman constant) & 0.41 \\
\hline d (displacement height $)^{1}$ & $0.189 \mathrm{~m}$ \\
\hline $\mathrm{z}_{0}(\text { surface roughness })^{1}$ & $0.039 \mathrm{~m}$ \\
\hline$v$ (kinematic viscosity) & $1.56 \times 10^{-5} \mathrm{~m}^{2} \mathrm{~s}^{-1}$ \\
\hline $\mathrm{D}_{\mathrm{g}}$ (diffusivity of $\mathrm{NH}_{3}$ in air) ${ }^{2}$ & $2.28 \times 10^{-5} \mathrm{~m}^{2} \mathrm{~s}^{-1}$ \\
\hline R (specific gas constant of dry air) & $287 \mathrm{~J} \mathrm{~kg}^{-1} \mathrm{~K}^{-1}$ \\
\hline $\mathrm{g}$ (acceleration of gravity) & $9.81 \mathrm{~m} \mathrm{~s}^{-2}$ \\
\hline$c_{p}$ (heat capacity of air) & $1005 \mathrm{~J} \mathrm{~kg}^{-1} \mathrm{~K}^{-1}$ \\
\hline \multicolumn{2}{|l|}{ For $R_{a c}$ and $R_{b g}$} \\
\hline$\alpha^{1}$ & 65.24 \\
\hline $\mathrm{z}_{1}$ (height of the top of logarithmic wind profile) $)^{3}$ & $0.1 \mathrm{~m}$ \\
\hline \multicolumn{2}{|l|}{ For $\mathrm{R}_{\mathrm{w}}$ and $\mathrm{R}_{\text {sto }}$} \\
\hline $\mathrm{R}_{\mathrm{w}(\min )}(\text { minimal cuticular resistance })^{4}$ & $1 \mathrm{~s} \mathrm{~m}^{-1}$ \\
\hline$a^{4}$ & 0.074 \\
\hline$\frac{D_{\mathrm{O}_{3}}}{D_{\mathrm{NH}_{3}}}\left(\text { ratio of diffusivity of } \mathrm{O}_{3} \text { and } \mathrm{NH}_{3}\right)^{5}$ & $\frac{1}{1.6}$ \\
\hline LAI (leaf area index $)^{1}$ & $3.5 \mathrm{~m}^{2} \mathrm{~m}^{-2}$ \\
\hline$g_{\max }(\operatorname{maximal} \text { stomatal conductance })^{5}$ & $270 \mathrm{mmol} \mathrm{O}_{3} \mathrm{~m}^{-2}$ \\
\hline $\mathrm{g}_{\text {pot }}(\text { effect of phenological change on stomatal conductane })^{5}$ & 1 \\
\hline $\mathrm{g}_{\min }(\text { minimal stomatal conductance })^{6}$ & 0.1 \\
\hline$\alpha_{\text {PAR }}{ }^{6}$ & $0.009\left(\mu \mathrm{mol} \mathrm{m} \mathrm{m}^{2}\right)^{-1}$ \\
\hline $\mathrm{T}_{\mathrm{opt}}(\text { temperature for optimal stomatal conducatnce })^{6}$ & $26^{\circ} \mathrm{C}$ \\
\hline $\mathrm{T}_{\min }(\text { temperature for minimal stomatal conductance })^{6}$ & $12^{\circ} \mathrm{C}$ \\
\hline $\mathrm{VPD}_{\min }(\mathrm{VPD} \text { for minimal stomatal conductance })^{6}$ & $3 \mathrm{kPa}$ \\
\hline
\end{tabular}

1 Table S1. Constants used in the parametrization of the 2LCCPM. 


\section{For $\Gamma_{\text {sto }}$}

$\tau$ 2.88 days

$1 \quad{ }^{1}$ Massad et al., 2010, for summer grassland (values are available also for the other seasons)

$2 \quad{ }^{2}$ Spiller (1989)

$3 \quad{ }^{3}$ Nemitz et al., 2001, for oilseed rape

$4 \quad{ }^{4}$ Horváth et al., 2005, for summer, semi-natural grassland (values are available also for the other 5 seasons)

$6 \quad{ }^{5}$ Sutton et al., 2013, for grassland

$7 \quad{ }^{6}$ Emberson et al., 2000, for grassland

8

9 S2. Constants used in the soil evaporation calculation

10 Table S2. Constants used in the parametrization of soil evaporation.

\begin{tabular}{ll}
\hline Constants & Value \\
\hline $\mathrm{h}^{\mathrm{M}}$ (canopy height) & $0.3 \mathrm{~m}$ \\
$\mathrm{~K}_{\mathrm{cb}}(\mathrm{Tab})^{\mathrm{A}}$ (coefficient) & 0.7 \\
$\Delta \mathrm{z}_{\mathrm{E}}^{\mathrm{A}}$ (thickness of evaporation layer) & $0.125 \mathrm{~m}$ \\
\hline
\end{tabular}

$11{ }^{\mathrm{M}}$ recommended by Massad et al. (2010) for grass

12 A recommended by Allen et al. (1998) (for extensively grazed pasture)

13

14 


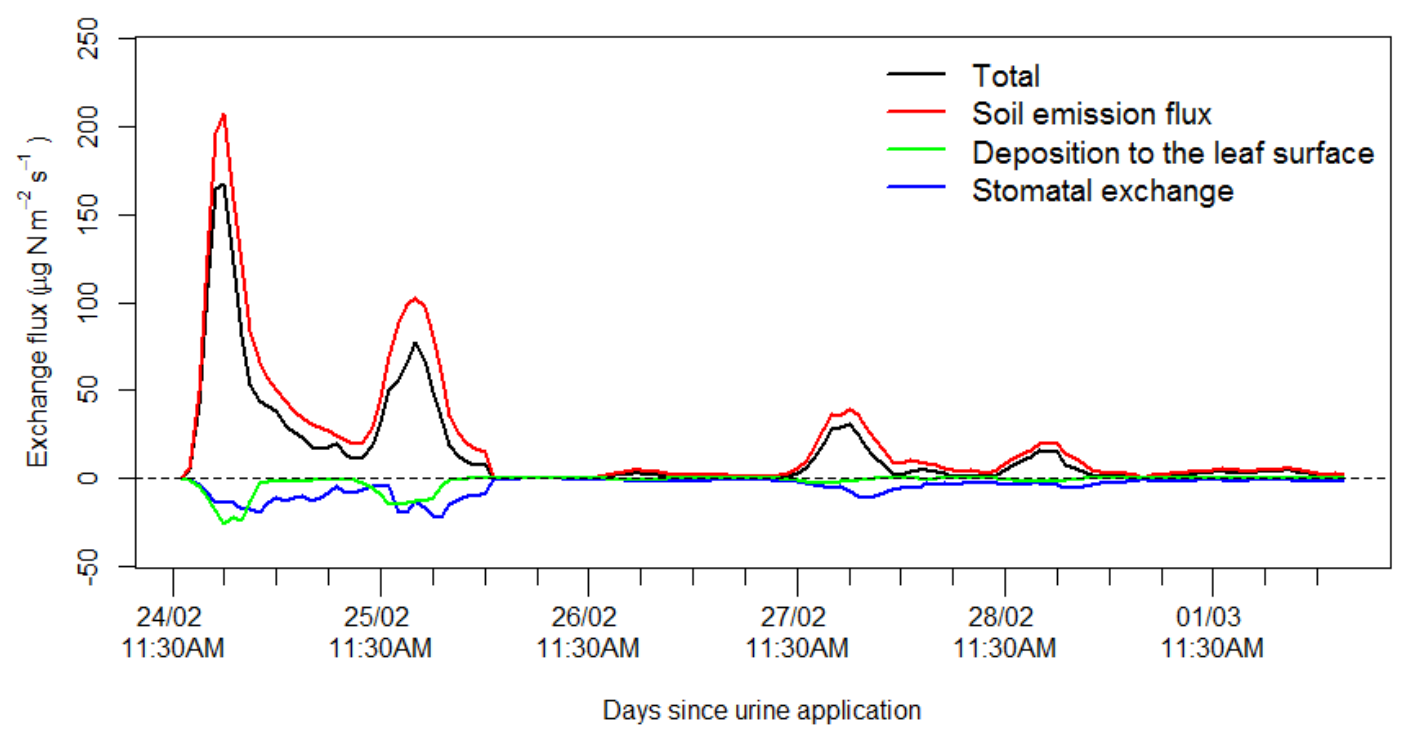

3 Figure $\mathrm{S} 1 . \mathrm{NH}_{3}$ fluxes simulated by the GAG model: Total $\mathrm{NH}_{3}\left(\mathrm{~F}_{\mathrm{t}}\right)$, soil emission flux $\left(\mathrm{F}_{\mathrm{g}}\right)$, deposition to the leaf surface $\left(\mathrm{F}_{\mathrm{w}}\right)$ and the stomatal exchange $\left(\mathrm{F}_{\mathrm{sto}}\right)$

\section{S4. Model experiment for a possible restart of urea hydrolysis after the rain event}

To test the model for a possible restart of urea hydrolysis after the rain event, we assumed that $10 \%$ of the urine ( 0.1 litre, containing $1.5 \mathrm{~g}$ of urea $\mathrm{N}$ ) was intercepted on the vegetation. From there due to the dry and warm weather conditions (according to the meteorological data in Fig. 10 , on the first day of the experiment relative humidity was particularly low and air temperature relatively high compared to the following days) the liquid content might evaporate quickly leaving behind dry urea, which could be washed into the soil by precipitation. With this 3 assumption, allowing the hydrolysis to restart in the soil, the model gives a better representation for the peaks in $\mathrm{NH}_{3}$ emission (Fig. 10d) on the following three days. In addition, a peak in both soil $\mathrm{pH}$ and TAN budget (Fig. S2 (a)-(b)) appears in the model results after the rain event, 6 similarly to the observed values of soil $\mathrm{pH}$ and $\mathrm{NHx}-\mathrm{N}$, respectively. 

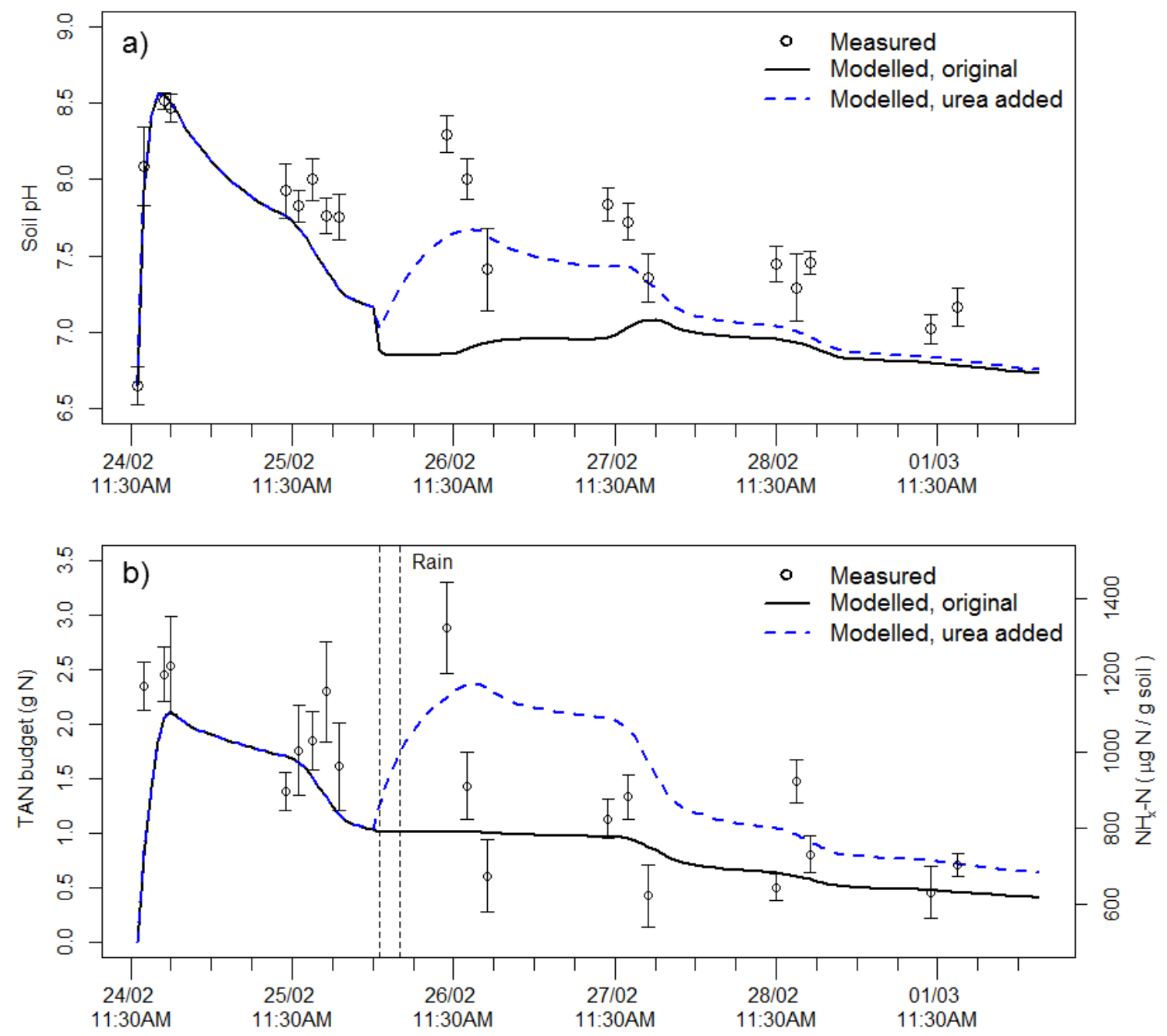

Days since urine application

2 Figure S2. Results for soil $\mathrm{pH}$ (a) and TAN budget (b) from the model experiment when an 3 assumed $1.5 \mathrm{~g}$ of urea was added in the beginning of the rain event. 


\section{S5. Investigation of model sensitivity to the timing of the rain event}

2 To test the model sensitivity to the timing of the rain event, we assumed the exact same hourly

3 precipitation sums and modified only the starting time of the rain event. In Fig. S3 (a) we show

4 how the timing of the rain event affects the $\mathrm{NH}_{3}$ emission, with up to a $6 \%$ reduction or $2 \%$ 5 increase in total $\mathrm{NH}_{3}$ emission. If it starts raining close to the time of the urine application, the

6 larger $\mathrm{R}_{\text {soil }}$ reduces the total emission by suppressing the first peak of emission (see Fig. S3 (b), 7 time step $\left.t_{3}\right)$.
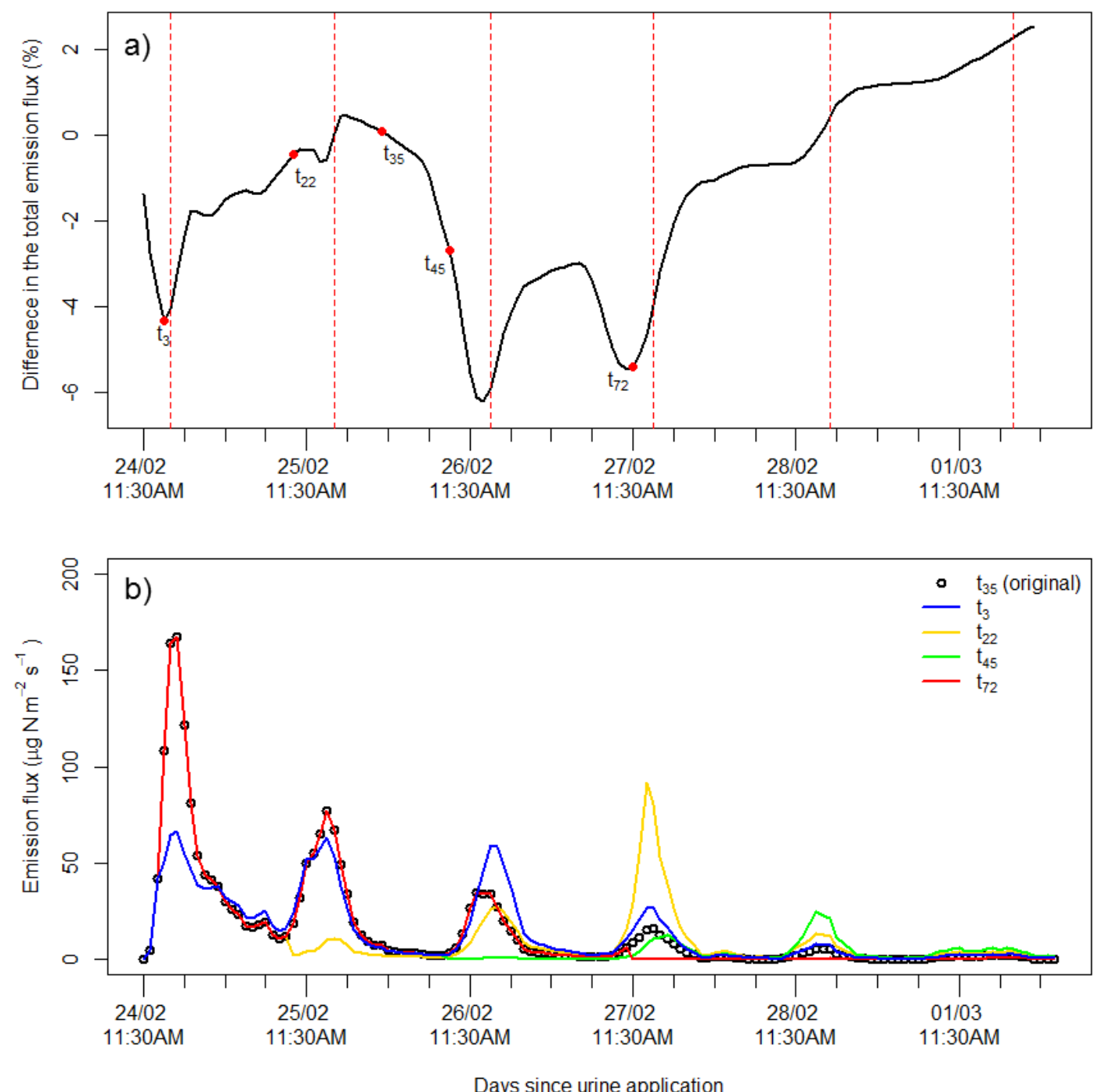

Days since urine application

9 Figure S3. (a): The total ammonia emission over the period for a given starting time of the rain event. Dashed red lines indicate the time of the daily maxima of soil temperature. (b): Hourly ammonia emission for the time steps indicated on panel (a) with red dots. 
1 Further local minima occur in the total emission two and three days after urine application,

2 when the rain event is close to the daily maxima of soil temperature which is when the daily

3 peak of $\mathrm{NH}_{3}$ emission is expected. In these cases also the increased soil resistance inhibits

4 volatilization. For example, in the $45^{\text {th }}$ time step (Fig. S3 (b)) the third peak of emission

5 disappeared. If we move the rain event after the daily maximum of soil temperature, the

6 prevented peak appears (not shown here) and at the same time increase of the total $\mathrm{NH}_{3}$

7 emission can be observed.

8 Nevertheless, if precipitation gets into the soil, when there is still enough TAN available for

9 volatilization apparently, the "trapped" TAN is emitted later on, as the soil resistance declines

10 due to evaporation. This will lead to a less low minimum in total emission. An example can be 11 seen for this phenomenon on Fig. S3 (b), when it started raining in the $22^{\text {nd }}$ time step, supressing 12 the second $\mathrm{NH}_{3}$ emission peak but enhancing the forth peak two days later, when the soil dried 13 out.

14 On the other hand, if precipitation occurs several days after the deposition of the urine patch (e.g. four or five days after urine application) total emission does not decline. This is because, after the third day the increased soil resistance prevents all the emissions after rainfall until the end of the period (Fig. S3 (b), $\mathrm{t}_{72}$ ). The reason for that is in this last period only a small amount of TAN is remaining in the soil, which is not able to overcome the effect of the soil resistance. Later, as the rain event passes the daily maximum temperatures, emission peaks appear, leading to an increase in total emission.

\section{Abbreviations}

\begin{tabular}{|l|l|}
\hline Abbreviation (unit) & Model variable \\
\hline$c_{\mathrm{p}}\left(\mathrm{J} \mathrm{kg}^{-1} \mathrm{~K}^{-1}\right)$ & Heat capacity of air \\
\hline $\mathrm{d}(\mathrm{m})$ & Displacement height \\
\hline $\mathrm{g}\left(\mathrm{m} \mathrm{s}^{-2}\right)$ & Acceleration of gravity \\
\hline $\mathrm{H}\left(\mathrm{J} \mathrm{m}^{-2} \mathrm{~s}^{-1}\right)$ & Sensible heat flux \\
\hline $\mathrm{h}(\mathrm{m})$ & Canopy height \\
\hline $\mathrm{k}$ & Karman constant \\
\hline
\end{tabular}




\begin{tabular}{|c|c|}
\hline $\mathrm{K}_{\mathrm{cb}}(\mathrm{Tab})$ & Coefficient to calculate ET \\
\hline $\mathrm{p}(\mathrm{kPa})$ & Surface atmospheric pressure \\
\hline q & Specific humidity \\
\hline $\mathrm{R}\left(\mathrm{kg}^{-1} \mathrm{~K}^{-1}\right)$ & Specific gas constant of dry air \\
\hline $\operatorname{Re}$ & Reynolds number \\
\hline $\mathrm{Sc}$ & Schmidt number \\
\hline $\mathrm{T}_{\min }\left({ }^{\circ} \mathrm{C}\right)$ & Temperature for minimal stomatal conductance \\
\hline $\mathrm{T}_{\mathrm{opt}}\left({ }^{\circ} \mathrm{C}\right)$ & Temperature for optimal stomatal conducatnce \\
\hline $\mathrm{T}_{\mathrm{v}}(\mathrm{K})$ & Virtual temperature \\
\hline VPD (kPa) & Vapour pressure deficit \\
\hline $\mathrm{VPD}_{\max }(\mathrm{kPa})$ & VPD for maximal stomatal conductance \\
\hline $\mathrm{VPD}_{\min }(\mathrm{kPa})$ & VPD for minimal stomatal conductance \\
\hline $\mathrm{x}$ & Parameter for calculating the stability functions \\
\hline $\mathrm{z}_{0}(\mathrm{~m})$ & Surface roughness \\
\hline$\alpha_{\mathrm{PAR}}\left(\mu \mathrm{mol} \mathrm{m} \mathrm{m}^{2}\right)^{-1}$ & Parameter for calculating $\mathrm{g}_{\mathrm{PAR}}$ \\
\hline$\delta_{0}(\mathrm{~m})$ & $\begin{array}{l}\text { Height where eddy and molecular diffusivity are the } \\
\text { same in magnitude }\end{array}$ \\
\hline$v\left(\mathrm{~m}^{2} \mathrm{~s}^{-1}\right)$ & Kinematic viscosity \\
\hline$\rho\left(\mathrm{kg} \mathrm{m}^{-3}\right)$ & Air density \\
\hline$\Psi_{\mathrm{H}}$ & Stability function for heat \\
\hline$\Psi_{\mathrm{M}}$ & Stability function for momentum \\
\hline
\end{tabular}

\section{References}

3 Allen, R. G., Pereira, L. S., Raes, D. and Smith, M.: Crop evapotranspiration-Guidelines for

4 computing crop water requirements, FAO Irrigation and drainage paper 56, FAO, Rome, Italy, 51998. 
1 Emberson, L., Simpson, D., Tuovinen, J.-P., Ashmore, M. and Cambridge, H.: Towards a

2 model of ozone deposition and stomatal uptake over Europe, EMEP MSC-W Note 6/2000, The

3 Norwegian Meteorological Institute, Oslo, Norway, 2000.

4 Garland, J. A.: The Dry Deposition of Sulphur Dioxide to Land and Water Surfaces, 5 Proceedings of the Royal Society of London A: Mathematical, Physical and Engineering Sciences, 354, 245-268, doi:10.1098/rspa.1977.0066, 1977.

Horváth, L., Asztalos, M., Führer, E., Mészáros, R. and Weidinger, T.: Measurement of ammonia exchange over grassland in the Hungarian Great Plain, Agr. Forest Meteorol., 130, 282-298, doi:10.1016/j.agrformet.2005.04.005, 2005.

Massad, R. S., Nemitz, E. and Sutton, M. A.: Review and parameterisation of bi-directional ammonia exchange between vegetation and the atmosphere, Atmos. Chem. Phys., 10, 1035910386, doi:10.5194/acp-10-10359-2010, 2010.

Nemitz, E., Milford, C. and Sutton, M. A.: A two-layer canopy compensation point model for describing bi-directional biosphere-atmosphere exchange of ammonia, Q. J. Roy. Meteor. Soc., 127, 815-833, doi:10.1256/smsqj.57305, 2001.

Owen, P. R. and Thomson, W. R.: Heat transfer across rough surfaces, J. Fluid Mech., 15, pp 321-33, doi:10.1017/S0022112063000288, 1963.

Paulson, C. A.: The Mathematical Representation of Wind Speed and Temperature Profiles in the Unstable Atmospheric Surface Layer, J. Appl. Meteorol., 9, 857-861, doi: 10.1175/15200450(1970)009<0857:TMROWS>2.0.CO;2, 1970.

Schuepp, P.: Turbulent transfer at the ground: On verification of a simple predictive model, Boundary Layer Meteorol., 12, 171-186, doi:10.1007/BF00121971, 1977.

Spiller, L.L.: Determination of Ammonia/Air Diffusion Coefficient Using Nafion Lined Tube, Analytical Letters, 22, 2561-2573, 1989.

Sutton, M. A., Reis, S., Riddick, S. N., Dragosits, U., Nemitz, E., Theobald, M. R., Tang, Y. S., Braban, C. F., Vieno, M., Dore, A. J., Mitchell, R. F., Wanless, S., Daunt, F., Fowler, D., Blackall, T. D., Milford, C., Flechard, C. R., Loubet, B., Massad, R., Cellier, P., Personne, E., Coheur, P. F., Clarisse, L., Van Damme, M., Ngadi, Y., Clerbaux, C., Skjøth, C. A., Geels, C., Hertel, O., Wichink Kruit, R. J., Pinder, R. W., Bash, J. O., Walker, J. T., Simpson, D., Horváth, 
1 dependent paradigm of ammonia emission and deposition, Philos. T. R. Soc. B, 368, 20130166, 2 doi:10.1098/rstb.2013.0166, 2013.

3 Webb, E. K.: Profile relationships: The log-linear range, and extension to strong stability, Q. J. 4 Roy. Meteor. Soc., 96, 67-90, doi:10.1002/qj.49709640708, 1970. 